\title{
ASSOCIATION BETWEEN VITAMIN D LEVELS AND ADOLESCENT IDIOPATHIC SCOLIOSIS
}

\author{
ASSOCIAÇÃO ENTRE OS NIVEIS DE VITAMINA D E A ESCOLIOSE IDIOPÁTICA DO ADOLESCENTE
} ASOCIACIÓN ENTRE LOS NIVELES DE VITAMINA D Y LA ESCOLIOSIS IDIOPÁTICA DO ADOLESCENTE

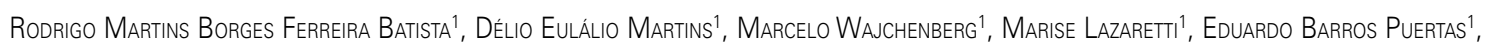
Maria Teresa de Sande e Lemos Ramos Ascensāo Terreril ${ }^{1}$, Liılan Fukusima Hayashi ${ }^{1}$

\begin{abstract}
Objective: To compare the levels of 25-hydroxyvitamin D in patients with AlS and a control group. Methods: The patients were recruited from the outpatient clinic of our institution during the year of 2013. Children diagnosed with scoliosis before 10 or after 18 years of age, and those suffering from neurological or muscular disorders, congenital malformations or genetic syndromes were excluded. The 25-OHD levels were determined by a fully automated electrochemiluminescence test. The appropriate level of 25-OHD was defined as greater than 30 ng/ $\mathrm{mL}$. The results were compared to a group of healthy individuals. Results: In group 1 (control) 63,3\% showed abnormal vitamin $D$ levels, while $91 \%$ of patients with AlS presented a low level of vitamin D. The mean BMI was $19.6 \mathrm{~kg} / \mathrm{m}^{2}$ for controls and $20.3 \mathrm{~kg} / \mathrm{m}^{2}$ for group 2 . Statistical analysis showed significant difference $(p<0.0001)$ between the levels of vitamin $D$. The average and minimum levels of vitamin $D$ were respectively 27 and $13.6 \mathrm{ng} / \mathrm{mL}$ for group 1 and 18.8 and $3.13 \mathrm{ng} / \mathrm{mL}$ for AlS group. Conclusions: Patients with AlS had statistically significant lower levels of 25-OHD than healthy patients. Further research should be conducted to investigate the actual impact of serum vitamin $D$ levels on the pathophysiology of AIS.
\end{abstract}

Keywords: Vitamin D; Avitaminosis; Scoliosis/etiology; Spinal diseases.

\section{RESUMO}

Objetivo: Comparar os níveis de 25-hidroxivitamina D em pacientes com EIA e um grupo controle. Métodos: Os pacientes foram recrutados no ambulatório de nossa instituição durante 2013. Crianças com escoliose diagnosticada antes de 10 ou após 18 anos de idade, portadoras de distúrbios neurológicos ou musculares, deformidades congênitas ou síndromes genéticas foram excluídas. Os níveis de 25-OHD foram determinados por teste de eletroquimioluminescência totalmente automatizado. O nível adequado de 25-OHD foi definido como acima de $30 \mathrm{ng} / \mathrm{ml}$. Os resultados foram comparados a um grupo de indivíduos saudáveis. Resultados: No grupo 1 (controle), 63,3 \% apresentaram níveis anormais de vitamina D, enquanto 91\% dos pacientes portadores de EIA apresentaram baixo nível de vitamina D. A média do IMC foi de 19,6 kg/m² para os controles e $20,3 \mathrm{~kg} / \mathrm{m}^{2} \mathrm{no}$ grupo 2 . A análise estatística demonstrou diferença relevante $(p<0,0001)$ entre os níveis de vitamina $D$. A média e os valores mínimos de vitamina D foram respectivamente 27 e 13,6 ng/ml para o grupo 1 e 18,8 e 3,13 ng/ml para o grupo ElA. Conclusões: Pacientes portadores de EIA tinham níveis de 25-OHD mais baixos do que os pacientes saudáveis, com significância estatística. O presente estudo sugere que a deficiência da vitamina D possa estar relacionada com a etiologia da escoliose idiopática do adolescente, corroborando dados da literatura. Mais pesquisas devem ser desenvolvidas para investigar o impacto real dos níveis séricos de vitamina D sobre a fisiopatologia da EIA.

Descritores: Vitamina D; Deficiência de vitaminas; Escoliose/etiologia; Doenças da coluna vertebral.

\section{RESUMEN}

Objetivo: Comparar los niveles de 25-hidroxivitamina $D$ en pacientes con EIA y un grupo control. Métodos: Los pacientes fueron reclutados en el ambulatorio de nuestra institución durante el año de 2013. Se excluyeron los niños diagnosticados con escoliosis antes de 10 años o después de 18 años, y quienes sufren de trastornos neurológicos o musculares, malformaciones congénitas o síndromes genéticos. Los niveles de 25-OHD se determinaron mediante un ensayo de electroquimiolumniscencia totalmente automatizado. El nivel apropiado de 25-OHD se define como mayor que $30 \mathrm{ng} / \mathrm{ml}$. Los resultados se compararon con un grupo de individuos sanos. Resultados: En el grupo 1 (control), 63,3\% tenían niveles anormales de vitamina D, mientras que el $91 \%$ de los pacientes con EIA mostraron bajo nivel de vitamina D. El IMC promedio fue $19,6 \mathrm{Kg} \cdot / \mathrm{m}^{2}$ para los controles y $20,3 \mathrm{Kg} . / \mathrm{m}^{2}$ para el grupo 2. El análisis estadístico mostró diferencias significativas $(p<0,0001)$ entre los niveles de vitamina $D$. Los valores medios y mínimos de vitamina $D$ fueron respectivamente 27 y $13,6 \mathrm{ng} / \mathrm{ml}$ para el grupo 1 y 18,8 y 3,13 ng/m/ para el grupo EIA. Conclusiones: Los pacientes con EIA tenían niveles más bajos de 25-OHD que los pacientes sanos, con significación estadística. Este estudio sugiere que la deficiencia de vitamina D puede estar relacionada con la etiología de la escoliosis idiopática del adolescente, lo que confirma los datos publicados. Más investigación debe llevarse a cabo para investigar el impacto real de la concentración de vitamina $D$ en la fisiopatología de la EIA.

Descriptores: Vitamina D; Avitaminosis; Escoliosis/etiología; Enfermedades de la columna vertebral.

1. Universidade Federal de São Paulo, São Paulo, Brazil.

Study conducted at the Spine Group of the Department of Orthopedics and Traumatology of the Universidade Federal de São Paulo, São Paulo, Brazil. Correspondence: Rua Borges Lagoa, 783, 5ªndar, Vila Clementino, São Paulo, SP, Brasil. 04038-031. rodrigoferreirabatista@gmail.com 


\section{INTRODUCTION}

Idiopathic scoliosis is the most frequently diagnosed spinal deformity, affecting $2 \%$ to $4 \%$ of children. ${ }^{1}$ It is a three-dimensional deformity, with alterations in the frontal, sagittal and axial planes, in the absence of congenital malformations, neuromuscular diseases, metabolic disorders or genetic syndromes.

The cause is still unknown, and there is no theory that explains all the aspects of this deformity. It is accepted that its etiology is probably multifactorial, ${ }^{1,2}$ resulting from a combination of genetic and environmental factors. Structural alterations of the vertebral and paravertebral tissues, and neuromuscular, proprioceptive, hormonal and biomechanical factors may be involved in the genesis of this disease, and there is also a clear association with age, sex and growth. ${ }^{1,2}$

The genetic heritage of scoliosis probably involves multiple genes and genetic polymorphisms. ${ }^{1}$ It is known that female patients with idiopathic scoliosis tend to be taller and thinner, and there is evidence of abnormal growth patterns. ${ }^{1}$

Scoliosis can occur through de novo mutation, but it is common to find more than one individual affected in the same family. The incidence is higher among first-degree relatives, and the inheritance pattern remains undefined. ${ }^{2}$

Skeletal maturity, potential remaining growth and age at menarche are classic risk factors for curve progression. ${ }^{3}$ Recent evidence suggests that osteopenia may also be a risk factor for progression. ${ }^{1,4}$

Some studies suggest an association between the development of adolescent idiopathic scoliosis (AIS) and polymorphisms of the vitamin $\mathrm{D}$ receptor (VDR) gene, a molecule that is crucial for maintaining adequate bone density. ${ }^{4-7}$

Vitamin D has been extensively studied in recent years, and the importance of this structure has been found to surpass the musculoskeletal benefits, ${ }^{4,8,9}$ acting in more than 30 organs and 200 genes $^{10}$ and exercising influence on the cardiovascular apparatus and the immune system. . $^{4,8}$ It is also associated with a reduced risk of certain neoplastic diseases, such as colon, breast and prostate cancer. ${ }^{10}$

It appears in the form of $D_{2}$ (ergocalciferol) in plants and $D_{3}$ (cholecalciferol) in animals. The estimated required daily intake of vitamin D is around $4000 \mathrm{IU} .{ }^{10-12}$ Ninety percent originates from the cutaneous production of this molecule, under the action of ultraviolet (UV) radiation, which justifies lower levels of 25-hydroxyvitamin D (calcidiol), a metabolite that is generally administered at higher latitudes and in late winter. The remainder, around $400 \mathrm{UI}$, must be ingested mainly from oily fish (tuna, sardines, salmon), eggs and fortified foods. ${ }^{10,12,13}$

Vitamin D, whether produced in the skin or absorbed, is hydroxylated in the hepatic tissue to $25-\mathrm{OH}$-vitamin $\mathrm{D}$ (calcidiol), and once again hydroxylated in the kidneys under the influence of parathyroid hormone (PTH) to 1alpha,25-dihydroxyvitamin D (calcitriol), which is the metabolically active form. ${ }^{10,13}$ (Figure 1) The second hydroxylation can also occur in inflammatory processes in the peripheral tissues, through the action of cytokines. Calcitriol is an important regulator of calcium homeostasis, and is necessary for the maintenance of muscle strength. 1,10,11,13

The level of vitamin $D$ is considered normal if above $30 \mathrm{ng} / \mathrm{mL}$, insufficient between 20 and 30, and deficient if below $20 \mathrm{ng} / \mathrm{mL}$, according to the American Society of Endocrinology. 1,10,12,13

This study assesses the association of serum vitamin $D$ levels (25-hydroxyvitamin D) with the occurrence of adolescent idiopathic scoliosis.

\section{METHODS}

The project was duly submitted to the Plataforma Brasil electronic system (062600/2013) and approved by the Research Ethics Committee of our institution, under number CEP 211236.

The cases were selected from the Spinal Outpatient Clinic of the institution in the first half of 2013, recruiting patients with scoliosis diagnosed between 10 and 18 years of age, regardless of their ethnicity or sex. Patients with congenital deformities, neuromuscular diseases and genetic syndromes were excluded from the study group, as were any patients with metabolic disorders related to

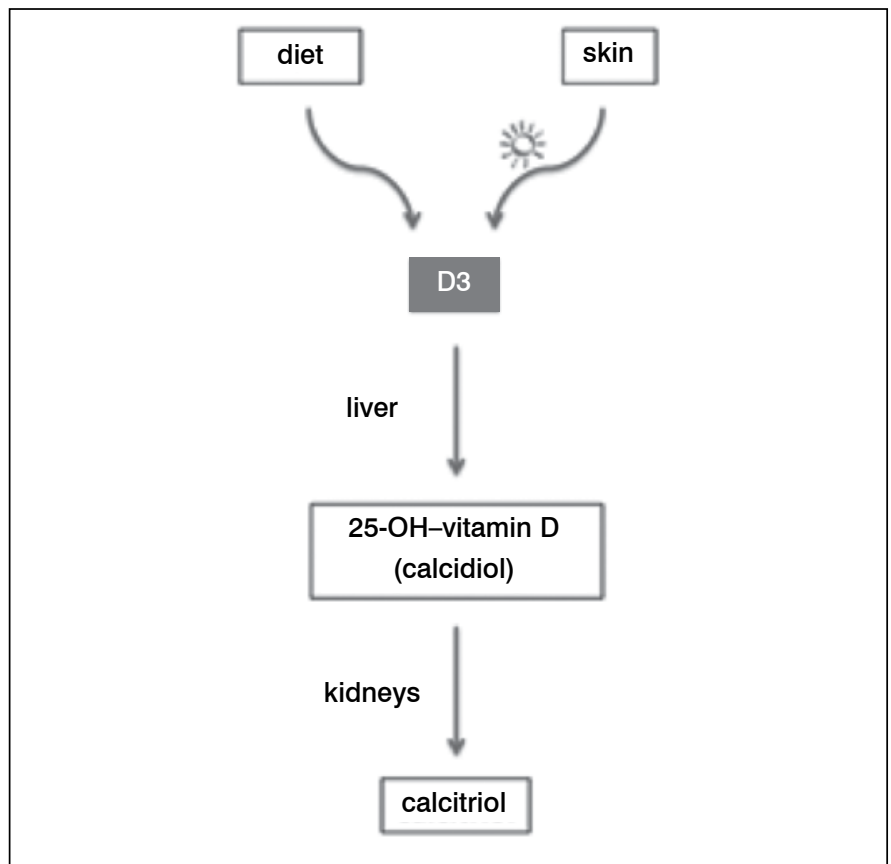

Figure 1. Metabolism of Vitamin D (D3 = cholecalciferol).

calcium and phosphorus homeostasis, thyroid or parathyroid endocrinopathies, absorption disorders and nephropathies. The enrolled patients (Group 1) read and signed the Informed Consent Form.

The control group (Group 2) was composed of normal individuals taken from the database of the institution's Rheumatology Discipline. It does not include individuals with rheumatic diseases, or patients on chronic medication.

Fifty-eight patients with scoliosis were initially selected. Two were excluded as they had been diagnosed before the age of ten years, and one as this patient presented signs suggestive of cerebral palsy. Thus 55 patients formed group 1. Group 2 was comprised of 60 patients.

The patients in group 1 were aged $12-47$ years $(20 \pm 7.7)$, while those in group 2 were between four and 19 years $(13.6 \pm 3.4)$. Most of the patients were female, $93 \%$ in group 1 and $80 \%$ in group 2 . In group $1,43.64 \%$ of the patients were White, $53 \%$ of mixed race and $0.36 \%$ Black. In group 2, 58.3\% of the patients were White, $36.7 \%$ of mixed race and $5 \%$ Black.

In group 2, all the patients had a BMl of $20-25 \mathrm{~kg} / \mathrm{m}^{2}$, and were considered eutrophic. In group 1 there were $72.7 \%$ eutrophic patients, $12.7 \%$ had below-normal BMI ( $<$ P5), and $14.5 \%$ had elevated $\mathrm{BMI}$ (> P85), criteria adopted by the Center for Disease Control and Prevention (CDC). (Figure 2)

Peripheral blood was drawn from cases and controls in early spring, late September and early October, a time of the year when we find the lowest levels of 25-OH-vitamin D. After fasting for 8 hours, $30 \mathrm{~mL}$ samples were taken from each patient then immediately centrifuged and frozen for storage until all the material was available for processing.

Total calcium (colorimetric method), phosphorus (colorimetric method), urea (UV kinetic method), creatinine (colorimetric kinetic) and parathyroid hormone (PTH) (electrochemiluminometric method) levels were determined to rule out impaired kidney function and secondary hyperparathyroidism. Levels of 25-hydroxyvitamin D (25OHD) were determined using the commercial kit Elecsys ${ }^{\circledR}$ Vitamin D Total, fully automated electrochemiluminescence immunoassay (Roche). Levels below $30 \mathrm{ng} / \mathrm{mL}$ were considered insufficient and below 20 $\mathrm{ng} / \mathrm{mL}$ deficient.

Besides the blood samples, anthropometric data such as stature and weight were measured in cases and controls, to calculate the body mass index (BMI).

The data obtained were submitted to the D'Agostino-Pearson normality test. The comparison relative to the categorical variables 


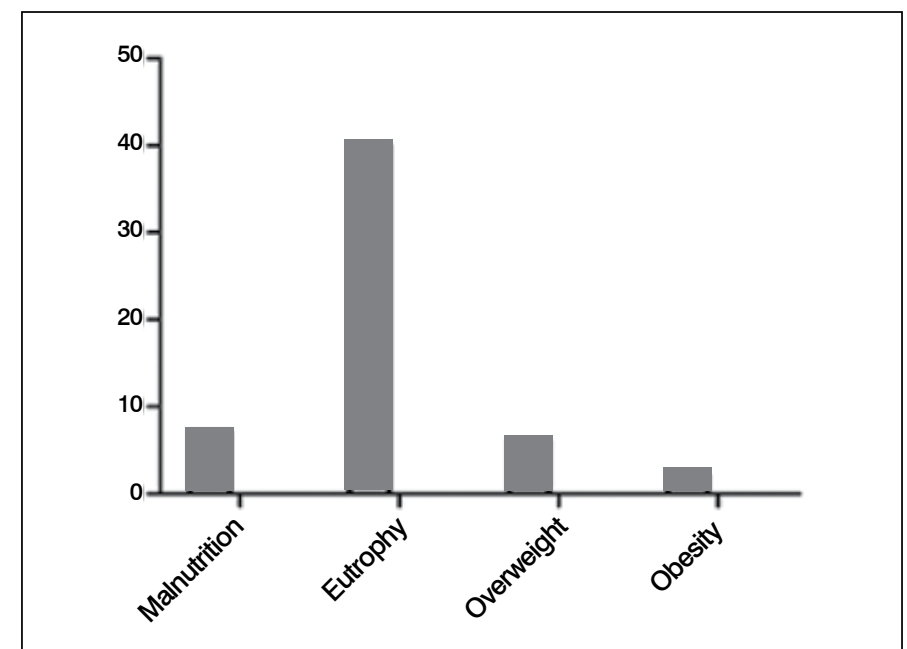

Figure 2. Number of cases by BMl category in the patients with AIS.

was made using Spearman's test, while Pearson's test was applied to the numerical variables. To compare vitamin $D$ levels between cases and controls, the data were submitted to the Student's t-test. The significance level was $5 \%$ for all the tests.

\section{RESULTS}

Creatinine, calcium, phosphorus and parathyroid hormone levels of the cases and controls were within normal limits. (Table 1)

In group 1, 34 patients (62\%) had 25OHD levels below $20 \mathrm{ng} / \mathrm{mL}$, $16(29 \%)$ below $30 \mathrm{ng} / \mathrm{mL}$ and five (9\%) patients presented normal levels, above $30 \mathrm{ng} / \mathrm{mL}$. The minimum value for this group was 3.13 , the maximum 39.77, and the mean $18.83( \pm 7.9)$. In group 2 , the levels ranged between 13.58 and 41.73 , mean $27.05( \pm 7.12)$. Eleven patients (18.3\%) had levels below $20 \mathrm{ng} / \mathrm{mL}, 27$ (45\%) below $30 \mathrm{ng} / \mathrm{mL}$, and $22(36.7 \%)$ presented normal levels. (Figure 3)

All the parameters evaluated were submitted to the D'AgostinoPearson normality test, which confirmed the normal distribution of the variables analyzed.

The correlation between the variables BMI and $250 \mathrm{HD}$ was investigated for group 1 and between the groups. The correlation between the BMI and 25OHD categories within group 1 was calculated using Spearman's correlation test, obtaining a correlation coefficient $(r)$ of $0.095(p=0.49)$.

The correlation between the absolute numerical values of BMI and of $250 \mathrm{HD}$ was performed using Person's correlation test, and the correlation coefficients obtained were $r=0.034(p=0.8)$ for group 1 (Figure 4), and $r=-0.121(p=0.36)$ for group 2. (Figure 5)

The statistical analysis of the categorical variables of vitamin $D$ between the two groups was performed using the Mann Whitney test $(p<0.0001)$. The statistical calculations relating to the numerical data were performed by the unpaired t-test in three stages. Firstly, considering all the cases, we observed lower levels of vitamin $D$ in group $1, p<0.0001$. (Figure 6) The same calculations were performed in the subsequent stages, excluding cases over 30 and 20 years of age, and the result was the same $(p<0.0001)$.

Table 1. Description of the results of $\mathrm{C}, \mathrm{Ca}, \mathrm{P}$ and PTH for cases and controls.

\begin{tabular}{c|c|c|c|c|c|c|c|c}
\hline & \multicolumn{2}{|c|}{ Minimum } & \multicolumn{2}{c|}{ Maximum } & \multicolumn{2}{c|}{ Mean } & \multicolumn{2}{c}{ SD } \\
\cline { 2 - 9 } & 1 & 2 & 1 & 2 & 1 & 2 & 1 & 2 \\
\hline Creatinine (mg/dL) & 0.36 & 0.5 & 1.03 & 1.2 & 0.63 & 0.77 & 0.12 & 0.16 \\
\hline Calcium (mg/dL) & 7.6 & 9 & 11.6 & 11 & 9.1 & 9.98 & 0.62 & 0.52 \\
\hline Phosphorus (mg/dL) & 2.7 & 2.7 & 5.2 & 6.3 & 3.93 & 4.23 & 0.57 & 0.77 \\
\hline $\begin{array}{c}\text { Parathyroid } \\
\text { hormone }(\mathrm{pg} / \mathrm{mL})\end{array}$ & 15 & 11.37 & 57.2 & 76.38 & 33.75 & 30.65 & 10.3 & 14.93 \\
\hline
\end{tabular}

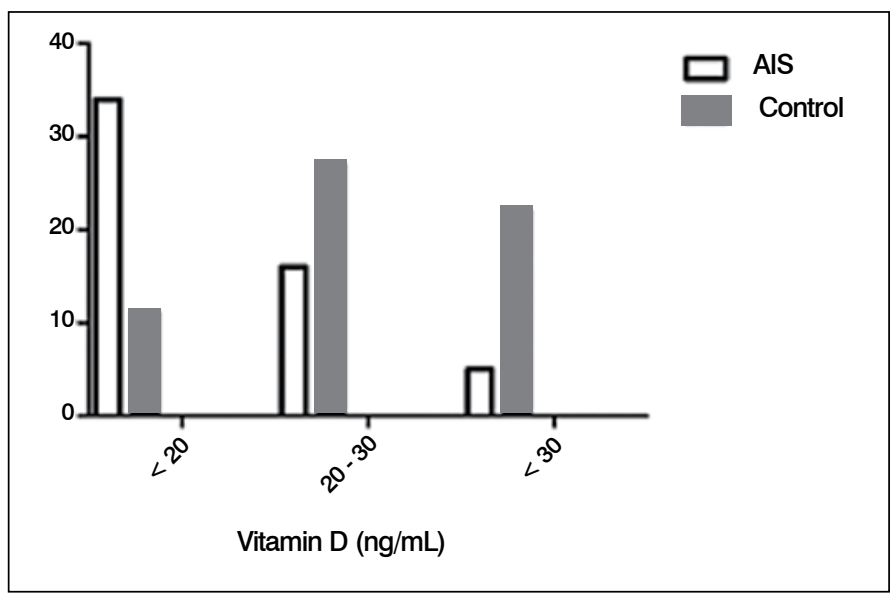

Figure 3. Absolute number of patients by level of vitamin D.

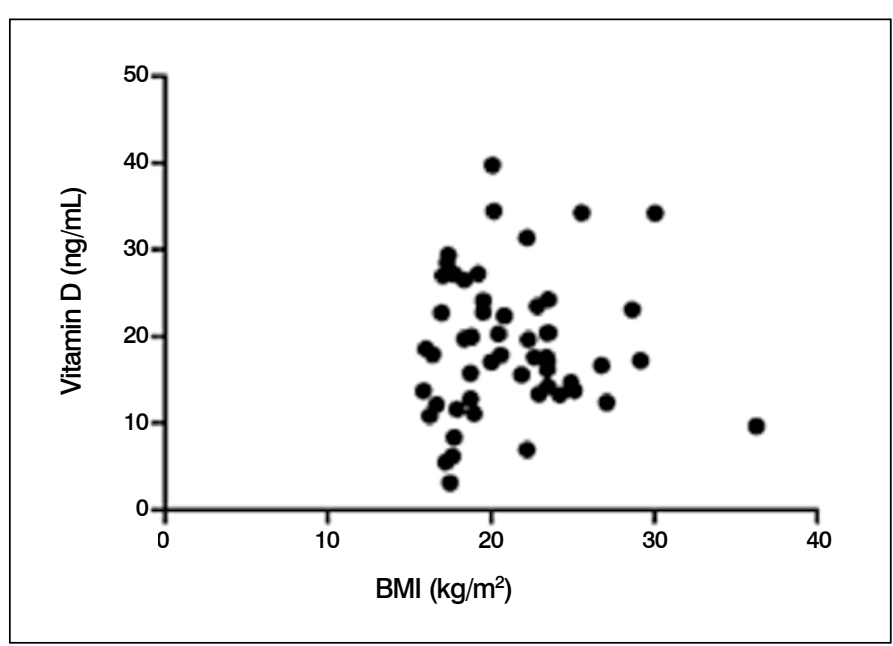

Figure 4. BMI $\times$ Vitamin D correlation in group 1.

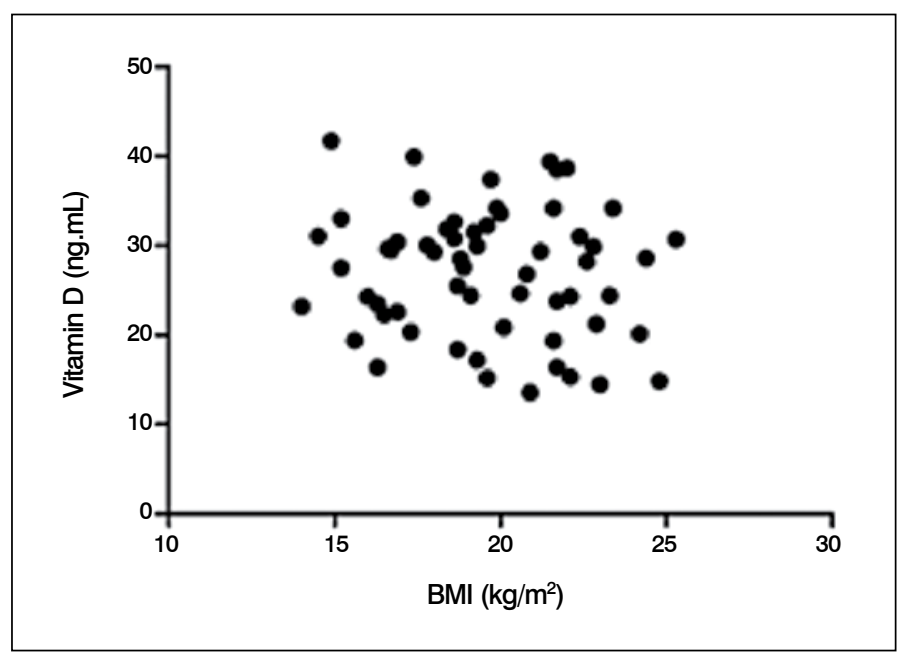

Figure 5. BMI x Vitamin D correlation in group 2.

\section{DISCUSSION}

Vitamin D acts as a hormone in the human body. ${ }^{8}$ Produced by the skin or ingested, it is metabolized and the end product of this pathway acts in various systems and performs vital roles in maintaining the structure and function of the musculoskeletal tissues. ${ }^{4,10}$ Recent evidence suggests a material impact of vitamin $D$ on bone mineral density and on the development of deformities, such as adolescent idiopathic scoliosis. ${ }^{4-7}$ 


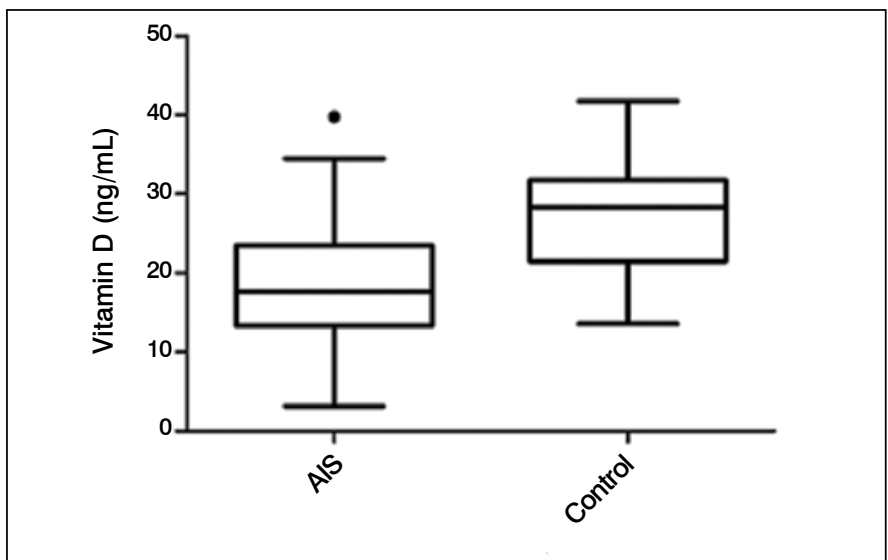

Figure 6. Vitamin D in groups 1 and 2 .

Demographic analysis of the groups shows that they are well paired for the variables sex and ethnicity. As regards the variable age, the possible impact of the extreme values found in group 1 (eight patients over 30 years of age), was minimized by the calculations of vitamin $\mathrm{D}$ level comparison excluding patients $\geq 30$ years, and then excluding patients $\geq 20$ years of age. Moreover, we can consider that age was not a preponderant factor in the definition of $250 \mathrm{HD}$ levels, a variable more closely related to other factors discussed below.

The body mass index appeared normal in all the patients in group 2. In group 1 we found seven patients with BMI below normal for their age, and considered the finding compatible with the characteristic biotype of AIS patients. ${ }^{14}$ The two patients with elevated $\mathrm{BMl}$ above $30 \mathrm{~kg} / \mathrm{m}^{2}$ among the cases were over 30 years of age, and calculations were performed disregarding them. No correlation was noted between the variations in the body mass index among the cases and vitamin $D$ levels, demonstrating a weak influence of $\mathrm{BMI}$ on serum $250 \mathrm{HD}$ levels.

The normal results of calcium, phosphorus, creatinine, and parathyroid hormone allowed us to rule out the existence of renal and metabolic disorders that could interfere in the metabolic pathways of $250 \mathrm{HD}$.

Comparison of vitamin $D$ levels between the two groups, both as categorical and numerical variables, showed significant difference according to the Mann Whitney test and the t-test. There is a considerable difference between the means (18.83 in group 1; 27.05 in group 2). This result suggests a factor possibly involved in the pathophysiology of adolescent idiopathic scoliosis. Studies show the importance of vitamin $D$ in the maintenance of bone and muscle homeostasis, ${ }^{1,10,11,15}$ and changes in the quality of these tissues may create an environment favorable to loss of alignment and the installation of deformities. ${ }^{1,4-6}$

We know that several factors influence vitamin $D$ levels. Variations that can occur due to dietary habits, level of physical activity and amount of exposure to the sun were not covered in this study. ${ }^{4,10}$ Ninety percent of the recommended daily vitamin $D$ intake is determined by cutaneous production under ultraviolet radiation. ${ }^{10,13}$ Both groups were made up of children and adolescents with the same potential for sun exposure, as they are all from the same region, at the same latitude, and were studied at the same time of the year: early spring in Brazil, when vitamin D levels are lower due to limited exposure in the previous season. ${ }^{10,13}$

We must also consider that individuals with skeletal deformities are more insecure about their own bodies, a fact that may prevent them from exposing their bodies to the sun or engaging in physical and recreational activities like other children.

Group 1 contains some late postoperative individuals, patients in the adult phase operated more than 10 years ago. The possible impact of these extremes on our outcome was eliminated by excluding the older patients from the final analysis. The results show that when we eliminated patients over 20 years of age, we obtained the same result and the same degree of association ( $p<0.0001)$.

Evidence in the literature of the impact of a deficiency of the hormone studied on the musculoskeletal tissues ${ }^{1,9}$ confirms our hypothesis, and indicates a direction for studying the etiology of adolescent idiopathic scoliosis. Future surveys should be conducted to confirm the importance of $25 \mathrm{OHD}$ in the pathophysiology of AIS.

\section{CONCLUSION}

Patients with adolescent idiopathic scoliosis included in this survey have lower serum vitamin D levels in comparison to patients without spinal deformity. In both the cases and the controls, there was no association between body mass index and serum 25OHD levels. This study suggests that vitamin $\mathrm{D}$ deficiency may be related to the etiology of adolescent idiopathic scoliosis, corroborating data from the literature. However, many variables are involved in the regulation of $25 \mathrm{OHD}$ levels that were not covered in this preliminary study, and further studies are needed, to establish the true impact of this hormone on the development of spinal deformities.

All authors declare no potential conflict of interest concerning this article.

\section{REFERENCES}

1. Nowak R, Szota J, Mazurek U. Vitamin D receptor gene (VDR) transcripts in bone, cartilage, muscles and blood and microarray analysis of vitamin $D$ responsive genes expression in paravertebral muscles of juvenile and adolescent idiopathic scoliosis patients. BMC Musculoskelet Disord. 2012;13:259.

2. Wajchenberg $M$, Martins $D E$, Puertas EB. Aspectos genéticos da escoliose idiopática do adolescente. Coluna/Columna 2012;11(3):234-6.

3. Weinstein SL, Ponseti IV. Curve progression in idiopathic scoliosis. J Bone Joint Surg Am. 1983:65(4):447-55

4. Suh KT, Eun IS, Lee JS. Polymorphism in vitamin D receptor is associated with bone mineral density in patients with adolescent idiopathic scoliosis. Eur Spine J. 2010;19(9):1545-50.

5. Chen WJ, QiuY, Zhu F, Zhu ZZ, Sun X, Liu Z, Chen ZJ. Vitamin D receptor gene polymorphisms: no association with low bone mineral density in adolescent idiopathic scoliosis girls. Zhonghua Wai Ke Za Zhi. 2008;46(15):1183-6.

6. Xia CW, Qiu Y, Sun X, Qiu XS, Wang SF, Zhu ZZ, et al. Vitamin D receptor gene polymorphisms in female adolescent idiopathic scoliosis patients. Zhonghua Yi Xue Za Zhi. 2007:87(21):1465-9.

7. Sosa Henríquez M, Torres Ramírez A, Domínguez Cabrera C, Salido E, Saavedra Santana $P$, Barrios Y, et al. Genetic polymorphism of vitamin D receptor and osteoporosis. Med Clin
(Barc). 1998:110(17):646-50

8. Norman AW. From vitamin $D$ to hormone $D$ : fundamentals of the vitamin $D$ endocrine system essential for good health. Am J Clin Nutr. 2008;88(2):491S-499S.

9. Kawaguchi $Y$, Kanamori $M$, Ishihara $H$, Ohmori $K$, Matsui $H$, Kimura T The association of lumbar disc disease with vitamin-D receptor gene polymorphism. J Bone Joint Surg Am. 2002;84-A(11):2022-8.

10. Stroud ML, Stilgoe S, Stott VE, Alhabian O, Salman K. Vitamin D - a review. Aust Fam Physician. 2008:37(12):1002-5.

11. Cline J. Calcium and vitamin d metabolism, deficiency, and excess. Top Companion Anim Med. 2012;27(4):159-64.

12. Vieth R. Vitamin D supplementation, 25-hydroxyvitamin D concentrations, and safety. Am J Clin Nutr. 1999:69(5):842-56.

13. Lips P. Vitamin D physiology. Prog Biophys Mol Biol. 2006;92(1):4-8.

14. Tarrant RC, Lynch S, Sheeran P, O'Loughlin PF, Harrington M, Moore DP, et al. Low body mass index in adolescent idiopathic scoliosis: relationship with pre- and postsurgical factors. Spine (Phila Pa 1976). 2014;39(2):140-8.

15. Grant WB, Holick MF. Benefits and requirements of vitamin D for optimal health: a review. Altern Med Rev. 2005;10(2):94-111. 